\title{
Mineral Resource Potential of the Rich Mountain Roadless Area, Fannin and Gilmer Counties, Georgia
}

\author{
By \\ Michael P. Foose, U.S. Geological Survey \\ and
}

Robert M. Thompson, U.S. Bureau of Mines

\author{
Studies Related To Wilderness
}

Under the provisions of the Wilderness Act (Public Law 88-577, September 3, 1964) and related acts, the U.S. Geological Survey and the U.S. Bureau of Mines have been conducting mineral surveys of wilderness and primitive areas. Areas officially designated as "wilderness," "wild," or "canoe" when the act was passed were incorporated into the National Wilderness Preservation System, and some of them are presently being studied. The act provided that areas under consideration for wilderness designation should be studied for suitability for incorporation into the Wilderness System. The mineral surveys constitute one aspect of the suitability studies. The act directs that the results of such surveys are to be made available to the public and be submitted to the President and the Congress. This report discusses the results of a mineral survey in the Rich Mountain Roadless Area, Chattahoochee National Forest, Gilmer and Fannin Counties, Georgia. The area was classified as a further planning area during the Second Roadless Area Review and Evaluation (RARE II) by the U.S. Forest Service, January 1979.

\section{MINERAL RESOURCE POTENTIAL SUMMARY STATEMENT}

The Rich Mountain Roadless Area covers approximately 16,880 acres in mountainous northern Georgia. Geological surveys of this area show it to be underlain by folded and metamorphosed rocks of the Great Smoky Group and the Murphy sequence. Geochemical surveys that were carried out to identify mineral deposits or indications of mineralization failed to show any unusual concentrations of metals.

The study area has a low potential for metallic mineral resources. Resources of stone of aggregate exist in the area, but abundant alternative sources of crushed stone makes development of these resources extremely unlikely. Although no evidence of precious metals was found, the area has a low potential for resources of gold because gold has been produced from placers in streams immediately adjacent to the study area. Rocks underlying the area are partly correlative with those around the strata-bound base-metal deposits located near Ducktown, Tenn., but no evidence for that type of mineralization was found indicative of a potential for strata-bound basemetal deposits in the area. Recent seismic surveys indicate that natural gas may exist in rocks underlying this region at depths of between 5,000 to $45,000 \mathrm{ft}$. Speculative oil and gas lease applications have been filed for about 96 percent of this area, but deep drilling would be needed to evaluate the potential of this resource.

\section{INTRODUCTION}

The approximately 16,880 acres which make up the Rich Mountain Roadless Area are located in the Toccoa Ranger District, Chattahoochee National Forest, in Gilmer and Fannin Counties, Ga. The area is situated between the towns of Blue Ridge and Ellijay, Ga. and has an irregular boundary that is east of U.S. Highway 76, south of county highway 153, and north and west of county roads 216 and S1010 (Fig. 1). Numerous small roads extending in from this perimeter provide good access to the edges of the study area; however, only one primitive road passes through the central part. Trails and abandoned logging roads provide excellent foot access within the area.

The study area is situated in the central part of a 7- to 8-mile-diameter, roughly circular area that is slightly higher than surrounding parts of the Blue Ridge Physiographic Province. Ridges and valleys radiate outward from Rich Mountain, which is near the center of this feature. The area has a moderately rugged topography and altitudes range from $1,600 \mathrm{ft}$ to
4,081 ft. Although maximum relief is in excess of $2,400 \mathrm{ft}$, local relief is on the order of 800 to 1,800 ft. Slopes steeper than 20 degrees are common.

The study area is drained mainly by the southwest-flowing tributaries of the Ellijay and Cartecay Rivers. The northeast quarter of the area, however, is drained by tributaries of the Toccoa River, a part of the Tennessee Valley Basin.

Moderately heavy second-growth hardwood forests cover most ridges and slopes, but do not significantly restrict foot access. Locally heavy growths of laurel and rhododendron do impair access along many drainages.

\section{Previous Work}

The regional study of the geology and mineral resources of the Ellijay quadrangle by LaForge and Phalen (1913) remains the only work that specifically covers the Rich Mountain area. Subsequently, Furcron (1953) commented on this study in light of more recent findings. A result of detailed work near the Georgia - 


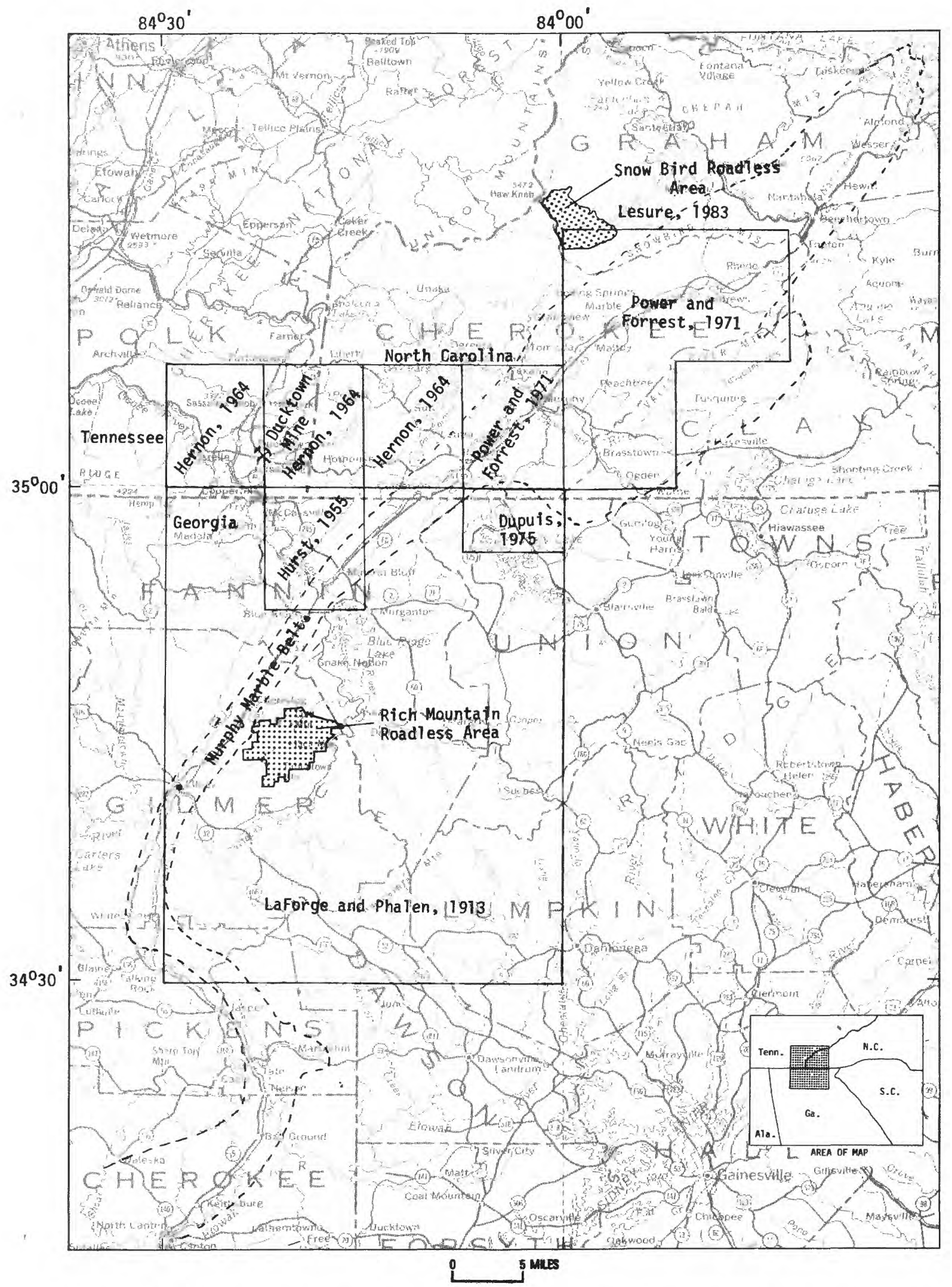

Figure 1.--Index map showing the location of the Rich Mountain Roadless Area in northern Georgia and sources for relevant geologic data. 
Tennessee line by Hurst (1955) and Dupuis (1975) is the recognition of basic stratigraphic, structural, and metamorphic elements that are present in the study area. Economic studies in adjacent areas have been done for gold (Yeates and others, 1896; Jones, 1909), iron (Phalen, 1908; Haseltine, 1924), manganese (Hull and others, 1911), and marble (McCallie, 1907). General studies of rocks of the Great Smoky Group that underlies most of this area have been made by Stose and Stose (1949) and Hadley (1970); the overlying Murphy sequence was characterized by Power and Forrest (1971; 1973) and Mohr (1973). Geologic syntheses that place this area in a regional perspective have been made by Butler (1973), Hurst (1973), Hatcher (1978), and Hatcher and others (1980).

\section{Present Work}

R. M. Thompson, V. P. Girol, G. C. Gazdik, and C. M. Martin conducted field studies for the U.S. Bureau of Mines (USBM) in October 1981. Activities included examination and sampling of rock exposures, stream sediments, mines, and prospects in or near the study area. Materials collected for further examination included 39 rock samples and 29 panned concentrates from stream sediments. Selected samples were semiquantatively analyzed by spectrographic methods for 42 elements by TSL Laboratories, Ltd., Spokane, Wash. Petrographic analyses of seven samples were performed at the USBM Reno Research Center, Reno, Nev. Additional microscopic evaluation of the heavy fraction of stream sediments was done by Thompson and Girol (1982).

IM. P. Foose, C. E. Brown, S. W. Nicholson, R. P. Koeppen, C. M. Sears, P. J. Atelsek, S. D. Ludington, and J. W. Whitlow did field investigations and sampling in this area for the U.S. Geological Survey (USGS) during parts of October and November 1981. Relatively uniform-spaced traverses were done in order to obtain both mapping coverage at the scale of $1: 24,000$ and soil, rock, and stream samples needed for a mineral assessment by means of geochemical analyses and petrographic studies. In addition to field observations, 201 rock, 78 fine-grained streamsediment, 57 unsorted stream-sediment, 41 pannedconcentrates from stream sediments, and 219 soil samples were collected. All samples were semiquantatively analyzed for 31 elements by opticalemission spectrographic methods and quantitatively analyzed for zinc and uranium at the USGS Laboratory, Denver, Colo. In addition, Foose and Nicholson petrographically examined 56 thin sections of rock. Other reports discuss the detailed results of these geologic (Foose, in press) and geochemical (Foose and Sears, in press; Sears and others, 1983) investigations.

\section{SURFACE- AND MINERAL-RIGHTS OWNERSHIP}

Forest Service records indicate Federal ownership of about 99 percent of the surface rights and 96 percent of the mineral rights in the study area. The outstanding one percent of the surface rights, with accompanying mineral rights, are privately owned. The Forest Service is presently conducting negotiations for fee acquisition of this privately owned tract. Private mineral-rights reservations in the study area are depicted in figure 2. All Federal lands were acquired under the authority of the Weeks Act of 1911 by the U.S. Department of Agriculture, Forest Service. Oil and gas lease applications, filed in 1979 and 1980 , include about 96 percent of the Federal mineral rights. These applications have not been acted upon as of August 1981.

\section{GEOLOGY}

The Rich Mountain Roadless Area is in the central of three northeast-trending belts of rocks which make up the Blue Ridge Province in this part of the Appalachian Mountains (Hatcher, 1978). This central belt is underlain mostly by Grenville-age basement rocks ( 1.0 to $1.1 \mathrm{~b} . \mathrm{y}_{0}$ ) and medium to highly metamorphosed clastic sediments of the Ocoee Supergroup and of the Murphy sequence in the synclinal Murphy belt. Thrust faults separate these rocks from a belt of similar but less metamorphosed rocks to the west and a belt of more volcanic-rich sediments to the east. Seismic studies (Cook and others, 1979) show all these rocks to have been thrust over relatively unmetamorphosed rocks that are now exposed west of the Blue Ridge Province.

The Rich Mountain area is underlain by sedimentary rocks of the Great Smoky Group and the Murphy sequence (Fig. 3). Three formations are recognized (Foose, 1983). The lowest is a sequence greater than $1,968 \mathrm{ft}$ thick that is predominantly metasiltstones, lesser metasandstones, and minor amounts of interlayered metaconglomerates and calcsilicates. These rocks are correlated with the Hothouse Formation as defined by Hurst (1955). They are gradationally overlain by a 2,625 - to 2,950 -footthick sequence that is predominantly mica schists with some interlayered metasiltstones, metasandstones, metaconglomerates, and calc-silicates and which is assigned to the Dean Formation (Hurst, 1955). The schists commonly have a distincitive texture as a result of large biotite porphyroblasts that have grown across the dominant rock foliation. These two formations are part of the Great Smoky Group and are overlain by distinctly different rocks of the Murphy sequence. The Nantahala Slate, which is the basal unit of this sequence, is the highest unit exposed in the study area and is finely laminated, gray to black carbonaceous slate.

Upper parts of the Murphy sequence have yielded Ordovician fossils (McLaughlin and Hathaway, 1973), indicating that the Nantahala Slate is early Paleozoic in age. The exact age of the underlying Great Smoky Group is uncertain, but it is generally considered to be late Precambrian to Early Cambrian.

Little agreement exists as to the environment in which these units were deposited. Fairley (1965) and Mohr (1973) speculate that all three formations were deposited in deep water. Hurst (1955) believes the Hothouse and Nantahala Formations are deepwater deposits, but that the Dean Formation was deposited in shallow water. Powers and Forest (1973) and Dupuis (1975) interpret the units to be shallowwater sediments. A recent synthesis (Hatcher, 1978) indicates that these sediments were probably deposited during a period of crustal rifting and tend to support a shallow to moderate depth as a depositional environment for these rocks.

These rocks have experienced multiple deformation and amphibolite-grade metamorphism. Two deformations are regionally identifiable; the first and most intense folding generated northeast-trending, step-shaped anticlinal folds that have gently dipping southeast limbs and steeply dipping northwest limbs. Although most are of small amplitude, these folds combine to form a relatively large anticlinal structure that passes through the center of the study area (fig. 3 ). These structures are cross-folded by indistinct and open northwest-trending folds, the effect of which is to reverse the plunge of the earlier fold axes from shallow northeast to shallow southwest.

Fault offsets have not been recognized within the study area. However, mylonites are locally present and show that some faulting has occurred. 


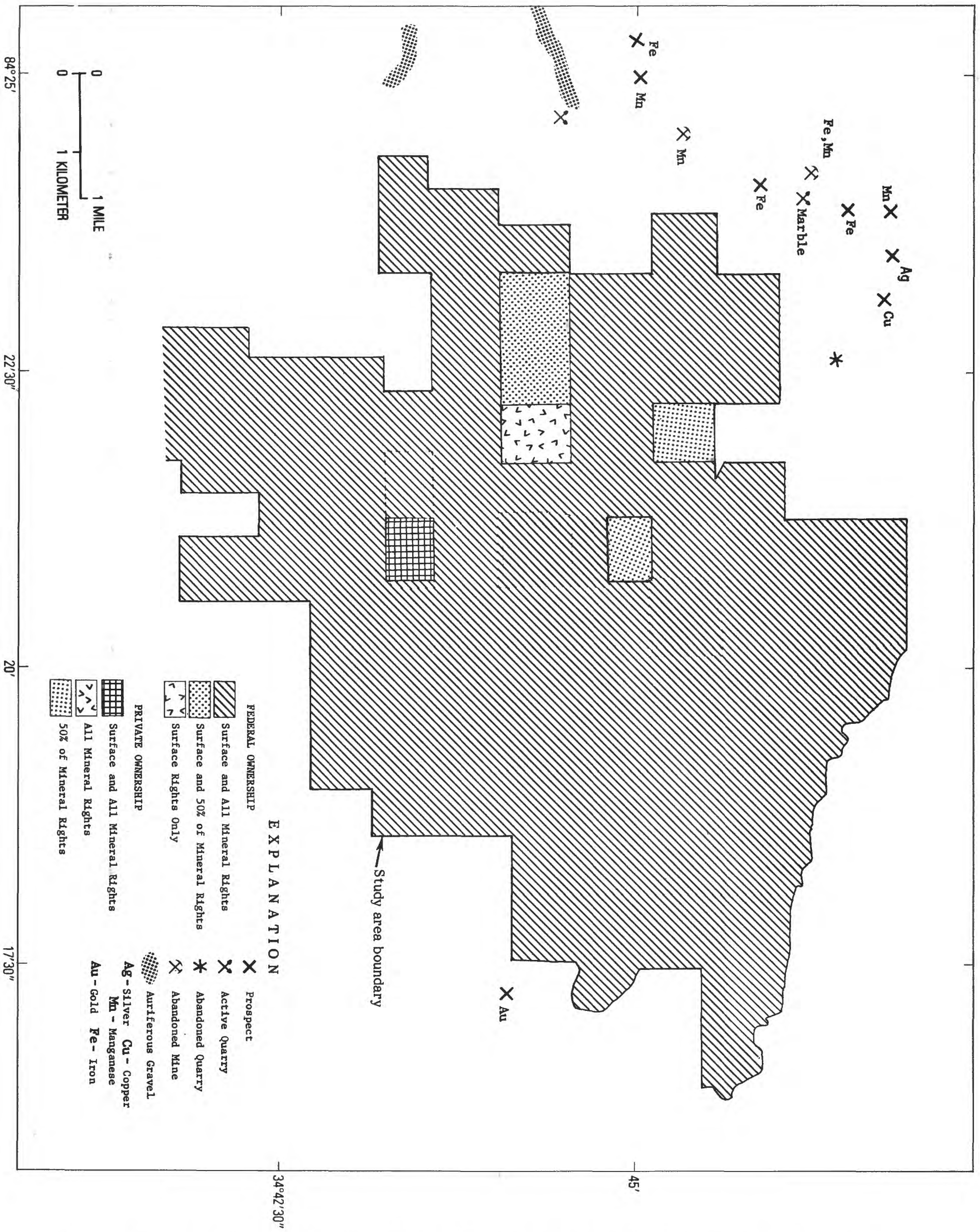

Figure 2.--Map showing the status of land in the Rich Mountain Roadless Area and location of adjacent mines and prospects. 
Additionally, several prominent northwest-trending lineaments pass through the study area and may be related to regional fault or fracture systems. The continuity of rock units across these lineaments, however, shows that only small offsets can be present across these features.

Mineral assemblages in the Rich Mountain Roadless Area are characteristic of the middleamphibolite facies of metamorphism. These assemblages, and detailed geothermometry and geobarometry studies by Nesbitt and Essene (1982), suggest metamorphism at $450^{\circ}$ to $540^{\circ} \mathrm{C}$ and at pressures of between 4 to 4.5 kilobars. Isotopic ages from other parts of the Blue Ridge Province indicate that peak metamorphism occurred about $450 \mathrm{~b} . \mathrm{y}$. ago, during the Taconic orogeny (Butler, 1973).

\section{GEOCHEMICAL SURVEY}

The geochemical evaluation of the study area is based on the trace-element analyses of 201 rock, 78 fine-grained stream sediments, 57 unsorted stream sediments, 41 panned concentrates from stream sediments, and 219 soil samples made by the USGS and on the 39 rock and 29 panned-concentrate samples collected by the USBM. Analyses of the USGS samples have been listed by Sears and others (1983) and discussed by Foose and Sears (in press).

No metallic deposits are known in the Rich Mountain Roadless Area. Further, the reconnaissance geochemical sampling of this area did not produce evidence of mineralization or even show the prescence of unusual concentrations of metallic elements. Local concentrations of high-background values can mostly be explained as resulting from chemical variations among rock units. Three slightly higher-than-normal concentrations of metallic elements found by this sampling are shown in figure 3 . All three clusters are associated with areas where bedrock is schist and reflect the slightly higher average abundance of many metals which occur within this rock type. None of these high-background concentrations is associated with recognizable mineralization and they are not considered to be significant.

Rock samples mostly show normal distributions of elements with values falling within ranges common for rocks of this type. Median values of schists, metasiltstones, and metasandstones closely matched published averages for either shales or sandstones. An exception is boron, which was unusually high and which reflects the relative abundance of the mineral tourmaline in these rocks. Most metals have lowest concentrations in metasandstones and greatest abundance in schists or slates. Vein quartz, which may act as a source for gold, has only background values of metallic elements.

Soil and stream samples (stream sediments, unsorted stream sediments, and panned concentrates) also failed to define anomolous areas. Their traceelement content mostly reflects local changes in bedrock, such that soils collected either over or downslope from areas of schists generally have the highest metal concentrations, as did samples collected from streams that drain areas of schists. Careful panning and laboratory processing of stream samples was completed in an unsuccessful attempt to locate gold, other heavy metals, or mineral suites that may be indicative of mineralization.

\section{MINERAL RESOURCE POTENTIAL}

Considerable mineral-related activity has occurred adjacent to the study area (fig. 2) and includes mining of iron, manganese, talc, and marble and the prospecting for copper and silver. Stone for road aggregate is quarried on White Path Creek, close to the area's western margin. The sites of all these activities are confined to stratigraphic units that overlie those in the study area and thus are not considered to reflect potential for similar resources within this area.

\section{Crushed Stone}

Conglomeratic sandstones occur within parts of the Great Smoky Group and may provide a source of crushed stone. However, they are relatively inaccessible and occur as discontinuous lenses; more easily worked sources of stone are readily available.

\section{Base Metals}

Rocks of the Great Smoky Group host the major base-metal sulfide deposit near Ducktown, Tenn. (fig. 1). The Copperhill Formation (Hurst, 1955), in which this strata-bound mineralization occurs, is stratigraphically below rocks in the study area. Further, Great Smoky Group rocks around Rich Mountain contain only trace amounts of sporadically distributed iron sulfides, have no significant metal anomalies, and show no unusual concentration of minerals that are commonly associated with sulfide deposits. There is low potential, therefore, for this type of base-metal deposit in the study area.

\section{Gold}

Gold has been reported in placers along streams issuing from the Rich Mountain Roadless Area and in veins located to the south and east. Placers on White Path Creek, near the study area's western margin, produced 5,000 troy ounces of gold (Yeates and others, 1896, p. 254) and four of the five largest gold nuggets found in Georgia (Cook, 1978); one of these weighed 4.5 pounds (LaForge and Phalen, 1913). Searches for a vein source of this gold have been unsuccessful (Yeates and others, 1896; LaForge and Phalen, 1913). Jones (1909) postulates the source to have been gold-bearing veins that have been removed by erosion.

Gold, or its companion element silver, were not detected in any samples. Gold was looked for in all samples by semiquantative methods (detection limit of $10 \mathrm{ppm}$ ) and in twenty samples that were considered mostly likely to have gold by atomic absorption methods (detection limit of $0.05 \mathrm{ppm}$ ). All samples of vein quartz were barren of sulfides and had only trace amounts of metals. Careful processing of the heavy fraction of stream sediments, both by panning and by laboratory heavy-liquid separation, failed to identify concentrations of gold. However, because of the area's past gold production, it has a low potential for occurrence of gold resources.

\section{Uranium}

Rock samples were quantitatively analyzed for uranium and field measurements on outcrops were made with hand-held four-channel gamma-ray scintillometers. All values recorded were background; little evidence of a potential exists for significant uranium resources.

\section{Oil and gas}

Recent seismic profiles across the southern Appalachians (Cook and others, 1979) show the metamorphic rocks in this region to have been thrust over layered sedimentary rocks which occur between 


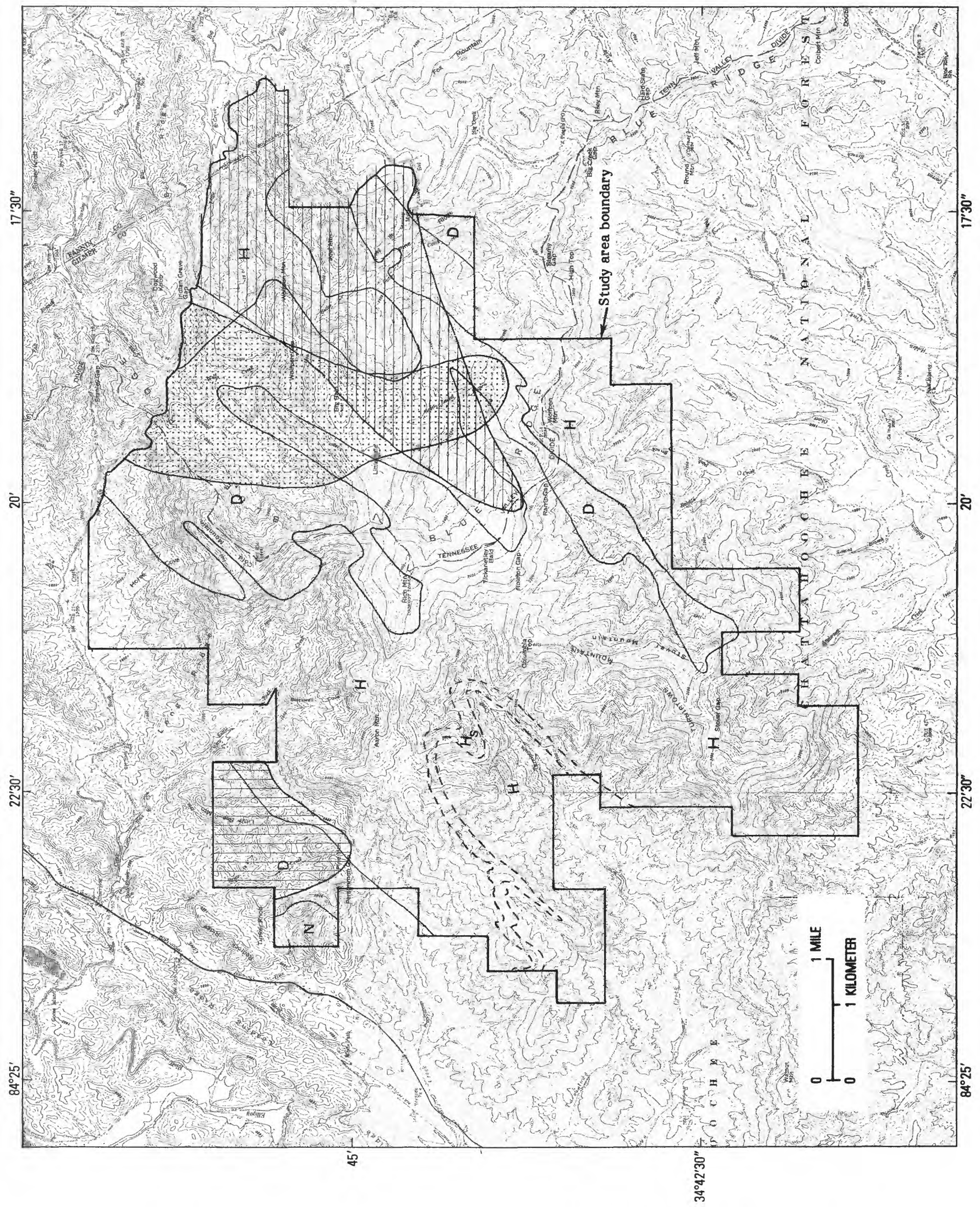

Figure 3.--Generalized geologic map of the Rich Mountain Roadless Area showing location of areas with high-background metal values. 


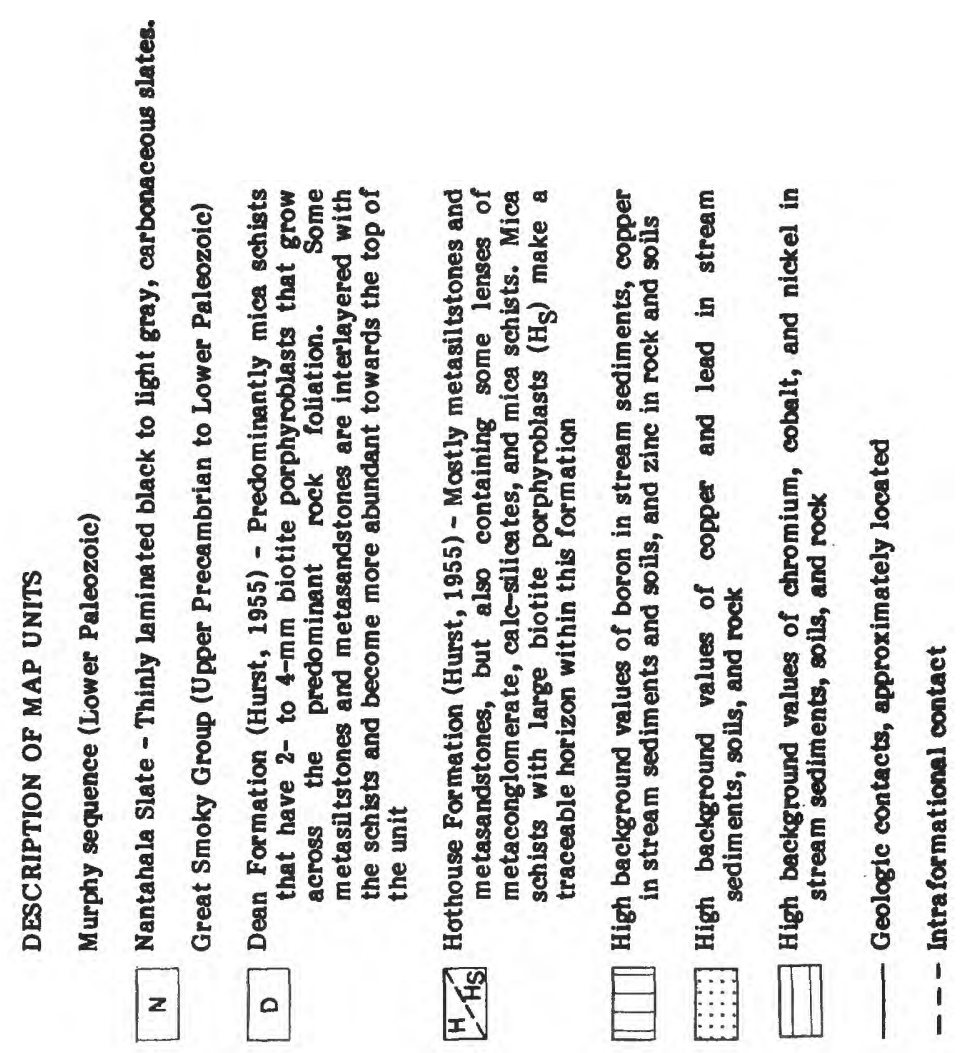


5,000 to $45,000 \mathrm{ft}$ below the surface. These findings have generated much interest in oil and gas exploration, with the result that spectulative oil and gas leases have been filed on about 96 percent of this area. The potential for hydrocarbon production from these layered sediments is unknown, but the depth and temperatures at which they occur make existence of liquid hydrocarbons unlikely. Natural gas, however, could be present. No reasonable estimate of this resource can be made without deep test drilling.

\section{REFERENCES}

Butler, J. R., 1973, Paleozoic deformation and metamorphism in part of the Blue Ridge thrust sheet, North Carolina: American Journal of Science, Cooper volume, v.273-A, p. 72-88.

Cook, F. A., Albaugh, D. S., Brown, L. D., Kaufman, Sidney, Oliver, J. E., and Hatcher, R. D., Jr., 1979, Thin-skinned tectonics in the crystalline southern Appalachians; COCORP seismicreflection profiling of the Blue Ridge and Piedmont: Geology, v. 7, no. 12, p. 563-567.

Cook, R. B., 1978, Minerals of Georgia - their properties and occurrences: Geological Survey of Georgia Bulletin 92, 189 p.

Dupuis, R. H., 1975, The stratigraphy, structure, and metamorphic history of the northern half of the Nottely Dam $7.5^{\prime}$ quadrangle, Georgia-North Carolina: unpublished masters thesis, University of Georgia, 149 p.

Fairley, W. M., 1965, The Murphy syncline in the Tate quadrangle, Georgia: Georgia Geological Survey Bulletin 75, $71 \mathrm{p}$.

Foose, M. P., in press, Geologic map of the Rich Mountain Roadless Area, Gilmer and Fannin Counties, Georgia: U.S. Geological Survey Miscellaneous Field Studies Map MF-1586-A.

Foose, M. P., and Sears, C. M., in press, Geochemical survey of the Rich Mountain Roadless Area, Gilmer and Fannin Counties, Georgia: U.S. Geological Survey Miscellaneous Field Studies Map MF-1586-B.

Furcron, A. S., 1953, Comments on the Ellijay quadrangle, Georgia-North Carolina-Tennessee, in Short contributions to geology, geography, and archaeology of Georgia, (no. 2): Geological Survey of Georgia Bulletin 60, p. 32-40.

Hadley, J. B., 1970, The Ocoee Series and its possible correlatives in Fisher, G. W., Pettijohn, F. J., Reed, J. C., Jr., and Weaver, K. N., eds., Studies of Appalachian geology-central and southern: Interscience, New York, p. 247-259.

Haseltine, R. H., 1924, Iron ore deposits of Georgia: Geological Survey of Georgia Bulletin 41, 222 p.

Hatcher, R. D., 1978, Tectonics of the western Piedmont and Blue Ridge, southern Appalachians-Review and speculations: American Journal of Science, vol. 278, p. 276-304.

Hatcher, R. D., Butler, J. R., Fullagar, P. D., Secor, D. T., and Snoke, A., 1980, Geologic synthesis of the Tennessee-Carolinas-northeast Georgia southern Appalachians: in Wones, D., ed., proceedings "The Caledonides in the U.S.A.", IGCP Project 2, memoir \#2, p. 83-90.

Hernon, R. M., 1964, Geologic maps and sections of the Ducktown, Isabella, and Persimmon Creek quadrangles, Tennessee and North Carolina: U.S. Geological Survey Open-File Report.

Hull, J. P. D., LaForge, Lawrence, and Crane, W. R., 1919, Report on the manganese deposits of Georgia: Geological Survey of Georgia Bulletin 35,295 p.
Hurst, V. J., 1955, Stratigraphy, structure and mineral resources of the Mineral Bluff quadrangle, Georgia: Georgia Geological Survey Bulletin 63, $137 \mathrm{p}$.

1973, Geology of the southern Blue Ridge belt: American Journal of Science, vol. 273, p. 643-670.

Jones, S. P., 1909, Second report on the gold deposits of Georgia: Geological Survey of Georgia Bulletin 19, $238 \mathrm{p}$

LaForge, Lawrence, and Phalen, W. C., 1913, Description of the Ellijay quadrangle (GeorgiaNorth Carolina-Tennessee): U.S. Geological Survey Geologic Atlas, Folio 187, 18 p.

Lesure, F. G., in press, Geologic map of Snowbird Roadless Area, Graham County, North Carolina: U.S.. Geological Survey Miscellaneous Field Studies Map, MF-1587-A.

McCallie, S. W., 1970, A preliminary report on the marbles of Georgia: Geological Survey of Georgia Bulletin 1, 126 p.

McLaughlin, R. E., and Hathaway, D. J., 1973, Fossils in the Murphy marble (abs.): Geological Society of America Abstracts with Programs, v. 5, p. 418-419.

Mohr, D. W., 1973, Stratigraphy and structure of part of the Great Smoky and Murphy belt groups, estern North Carolina: American Journal of Science, Cooper volume, vol. 273-A, p. 41-71.

Nesbitt, B. E., and Essene, E. J., 1982, Metamorphic thermometry and barometry of a portion of the southern Blue Ridge province: American Journal of Science, v. 282 , no. 5 .

Phalen, W. C., 1908, Iron ores near Ellijay, Ga.: U.S. Geological Survey Bulletin 340-E, p. 330-334.

Power, W. R., and Forrest, J. T., 1971, Stratigraphy and structure of the Murphy belt, North Carolina: Carolina Geological Society Field Trip Guidebook, North Carolina Department of Natural Resources, 29 p.

1973, Stratigraphy and paleogeography in the Murphy Marble belt: American Journal of Science, Vol. 273, p. 693-711.

Sears, C. M., Foose, M. P., Day, G. W., and Ericksen, IV. S., 1983, Analyses and descriptions of geochemical samples from the Rich Mountain Roadless Area, Gilmer and Fannin Counties, Georgia: U.S. Geological Survey Open-File Report 83-658.

Stose, G. W., and Stose, A. I. J., 1949, Ocoee series of the southern Appalachians: Bulletin of the Geological Society of America, v. 60, p. 267-320.

Thompson, R. M., and Girol, V. P., 1982, Mineral investigation of Rich Mountain RARE II Further Planning Area, Gilmer and Fannin Counties, Georgia: U.S. Bureau of Mines Open-File Report MLA 141-82.

Yeates, W. S., McCallie, S. W., and King, F. P., 1896, A preliminary report on a part of the gold deposits of Georgia: Geological Survey of Georgia Bulletin 4-A, 542 p. 